\title{
RESEARCH PAPER \\ Nutrimental Content and Functional Properties of Quinoa Flour from Chile and Mexico
}

\author{
Alma Vázquez-Luna ${ }^{1}$, Francisco Fuentes ${ }^{2}$, Eduardo Rivadeneyra ${ }^{3}$, Carmen \\ Hernández ${ }^{1,3}$, and Rafael Díaz-Sobac ${ }^{1}$ \\ ${ }^{1}$ Universidad Veracruzana, Instituto de Ciencias Básicas. Av. Dr. Luis Castelazo s/n, Col. Industrial \\ Animas, Xalapa, C.P. 91190, Veracruz, México. \\ ${ }^{2}$ Pontificia Universidad Católica de Chile, Facultad de Agronomía e Ingeniería Forest. Av. Vicuña Mackena \\ 4860, Macul Casilla 306-22. C.P. 6904411, Santiago, Chile. \\ ${ }^{3}$ Facultad de Química Farmacéutica Biológica, Calle de la Pérgola s/n, Zona Universitaria, Col. Centro, \\ Xalapa, Veracruz, México.
}

\begin{abstract}
A. Vázquez-Luna, F. Fuentes, E. Rivadeneyra, C. Hernández, and R. Díaz-Sobac. 2019. Nutrimental Content and Functional Properties of Quinoa Flour from Chile and Mexico. Cien. Inv. Agr. 46(2): 144-153. Knowledge related to the genetic improvement of quinoa has been increasing in recent years, demonstrating an effective advance in obtaining morphological characteristics meant to achieve uniformity in the quantity and quality of the production obtained in the field. For this research, quinoa flour harvested in Mexico and Chile, the latter of which was genetically improved, was obtained and characterized. Next, the determination of moisture, fats, fiber, carbohydrates, acidity, ash, proteins, polyphenols, and flavonoids was performed. Functional properties were also evaluated, and a microbiological count was made. No differences were observed in the odor and color of the flours, nor was there a change in moisture during 6 months of storage. The initial percentages of acidity, fats, proteins and ashes were higher in Chilean flour $(2.25,10.99,10.69$ and 3.54\%, respectively), while flour from Mexico presented $1.75,7.64,8.4$ and $3.17 \%$, respectively. Regarding raw fiber and carbohydrates, the results obtained were lower for Chilean flour (2.78 and 59.78\%, respectively), while Mexican flour showed 4.08 and $66.67 \%$, respectively. The content of flavonoids and polyphenols in Chilean flour were higher than those of Mexico. The results obtained reveal that the nutritional content of Chilean quinoa flour was better than that of Mexico. The growth of molds and yeasts was observed in the 6th month for the Mexican flour; however, the values did not exceed the limits of the OMN (Official Mexican Norm) 247.
\end{abstract}

Key words: Functional properties, nutrimental content, quinoa.

\section{Introduction}

The nutritional value of quinoa has been basically recognized by its high quality protein (FAO, 2013); it is particularly rich in essential amino acids and

Received Jan 30, 2019. Accepted Mar 20, 2019.

Corresponding author: radiaz@uv.mx carbohydrates, producing low glycemic indexes, and has a better nutrimental and functional quality in general compared to cereal grains such as corn, oats, wheat and rice (Romo et al., 2006; Torres, 2009). Recent studies show the nutritional richness of quinoa both in absolute terms and in comparison with other basic foods; in these studies, it is generally emphasized that quinoa 
proteins contain a balance of all the essential amino acids (Fuentes, 2008).

The biochemical analyses also show an adequate presence of vitamins, especially A, B and C, which are a fundamental part of a healthy diet. In addition, quinoa does not contain gluten (Arroyave, 2006). This grain is characterized not only by the nutritional quality it provides but also by the content of phenolic compounds that it gives to the diet (Taylor et al., 2014). The studies suggest that many bioactive foods (proteins and peptides, polyunsaturated fatty acids, fiber, phenolic, carotenoids, probiotics and prebiotics) can exert antioxidative, antithrombotic, hypocholesterolemic, antimicrobial and immunomodulatory effects (Padrón et al., 2014).

The quinoa grain is consumed in salads or typical dishes, is added to soups, is used as a cereal, and is even fermented it to obtain beer or "chicha", which is considered an Incan beverage; this result is achievable because maltose is the main sugar in the quinoa, making possible the process for the production of products that are involved in fermentation. It is also considered that in the form of flour, quinoa can act as a substitute for wheat in much of the baking industry, for example, in the preparation of cookies, hot cakes, biscuits, pastries, and cupcakes, among others (Villanueva, 2014; Vázquez et al., 2015; Hernández et al., 2016).

Recently, quinoa has been considered a potential native resource not only of Andean countries but also of other countries, given their interest in protein of high nutritional value, especially in regard to recently popularized diets, such as vegetarianism and veganism, in which quinoa can be included as a substitute for meat. In addition, quinoa presents advantages in its sugar composition. In the present work, quinoa flour from Mexico and Chile was obtained and characterized, with the differences in nutrient content determined for both newly obtained quinoa and quinoa after six months of storage.

\section{Material and Methods}

\section{Materials}

One kilogram washed and cleaned quinoa was used to obtain each of the flours. The quinoa from Mexico was purchased at a convenience store in Xalapa, state of Veracruz, and the Chilean quinoa was a donation from the Pontificia Universidad Católica de Chile. The washed and dried grains were ground for $10 \mathrm{~min}$ in a commercial brand blender (Osterizer, Milwauke, Wisconsin, USA) and subsequently sieved in a 200 mesh screen. The obtained flours were packed in laminated plastic bags and vacuum sealed with a sealing machine (Oster, Milwauke, Wisconsin, USA) after having been assigned a key for the analyses to follow in 6 months, and were stored at room temperature.

\section{Moisture}

Two melting pots, kept at a constant weight for $2 \mathrm{~h}$, were placed on a stove, then $1 \mathrm{~g}$ test material was placed in each melting pot, which were then placed back on the stove for approximately $4 \mathrm{~h}$; the material was returned to the melting pot to cool, and finally, the material was weighed for the first time to determine the percentage of moisture (Nielsen, 2003).

\section{Raw fat}

The fat content of the samples was determined through the official A.O.C.S Ab 3-49 (1996) method of Soxhlet.

\section{Raw fiber}

Raw fiber was determined by the official AOAC (1996) method, which consisted of submitting the dry and defatted sample first to acid hydrolysis and then to alkaline hydrolysis. The fiber content of the sample was gravimetrically calculated once it was calcined. 


\section{Carbohydrates}

A solution was made by adding $1 \mathrm{mg}$ test sample to $10 \mathrm{~mL}$ distilled water; a total of six tubes were prepared and in each tube was added: $1 \mathrm{~mL}$ test

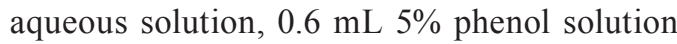
and $3.6 \mathrm{~mL}$ sulfuric acid. Thirty minutes later, the absorbance was determined at $480 \mathrm{~nm}$. The absorbance of the samples was determined. The standard curve was generated with glucose, which was also treated in the same way as the test material (NMX-F-312-1978).

\section{Reducing sugar}

The method was performed as previously described in NMX-F-006-1983, with modifications. First, $25 \mathrm{~mL}$ solution A was measured along with 25 $\mathrm{mL}$ solution $\mathrm{B}$, which were placed in a $500 \mathrm{~mL}$ Erlenmeyer flask attached to a universal support with a gauged burette. The flask was then placed under a boiler flask for titration. The solution was left until it boiled and started to be titrated dropwise; during the first color change, the titration was stopped, and $0.5 \mathrm{~mL}$ methylene blue was added, then the boiling was repeated. When the solution came to a boil, titration was repeated, resulting in an orange copper color due to the formation of cuprous acid. The same procedure was performed for the test with $1 \mathrm{~g}$ quinoa flour in $100 \mathrm{~mL}$ distilled water.

\section{Protein content}

Using the Biuret Method, $20 \mathrm{~mL}$ distilled water was applied to $1 \mathrm{~g}$ quinoa flour, then to the solution was added $50 \mathrm{~mL} 20 \%$ sodium sulfate and allowed to rest for $10 \mathrm{~min}$. Later, $2 \mathrm{~mL}$ was allocated to each tube before adding $2 \mathrm{~mL}$ sodium sulfate plus $8 \mathrm{~mL}$ Biuret. This was solution was then incubated in the dark for $30 \mathrm{~min}$, after which absorbance at $540 \mathrm{~nm}$ was determined. For the quantification, a standard curve was generated using bovine albumin.
Ashes

In a melting pot with constant weight, $3 \mathrm{~g}$ test material was burned in a direct fire until ash was formed without emitting smoke. The melting pot was taken to a stove to heat at $100{ }^{\circ} \mathrm{C}$ for $8 \mathrm{~h}$ and the calcination was completed. It was then cooled so that it could be weighed (NMX-F-066-S-1978).

$$
\text { Ashes } \%=(P-p) \times 100 / M
$$

$\mathrm{P}=$ Melting pot mass with ashes in grams

$$
p=\text { Mass of the empty melting pot }
$$

$$
\mathrm{M}=\text { Mass of the test in grams }
$$

\section{Polyphenols determination}

The determination of polyphenols was performed in triplicate for every experiment using the Folin Ciocalteu method. Gallic acid was used as a standard to generate a standard curve, starting with a phenol solution with a concentration 50 $\mathrm{mg} \mathrm{mL} \mathrm{m}^{-1}$. Three gram quinoa flour were placed in $10 \%$ methanol for $18 \mathrm{~h}$. Next, $200 \mu \mathrm{L} 3 \mathrm{~N}$ Folin Ciocalteu reagent was added, then the solution was agitated in a vortex for $3 \mathrm{~min}$ (Fisher Scientific G560 USA). Next, $2 \mathrm{~mL} \mathrm{7 \%} \mathrm{Na}_{2} \mathrm{CO}_{3}$ was added to $2.6 \mathrm{~mL}$ distilled water and incubated for an hour at room temperature, after which the absorbance was measured to $750 \mathrm{mn}$ using a UV-Vis spectrophotometer (Agilent, 8453), and the results were reported as milligram equivalents to gallic acid (mg EAG) per $100 \mathrm{~g}$ test material (Vázquez-Luna, et al., 2011).

\section{Flavonoids determination}

From the methanolic extracts, $250 \mu \mathrm{L}$ was taken, to which $1250 \mu \mathrm{L}$ distilled water and $75 \mu \mathrm{L} 5 \% \mathrm{NaNO}_{2}$ were added for homogenization, followed by 150 $\mu \mathrm{L} 10 \% \mathrm{AlCl}_{3}$; the results are expressed as $\mathrm{mg}$ of quercetin/100 g test (Vázquez-Luna et al., 2011). 


\section{Quantification per liquid chromatography}

To determine the photosynthetic pigments, a test volume of $20 \mu \mathrm{L}$ was introduced into the injector, which had been previously filtered with a nylon filter (pore size $0.2 \mu \mathrm{m}$ and a diameter of $25 \mathrm{~mm}$; ADVANTEC MFS) to eliminate impurities in the extract that could damage the column. This was then injected at a flux of $0.6 \mathrm{~mL} \mathrm{~min}^{-1}$ controlled by a quaternary peristaltic pump at room temperature with wavelength detection at $290 \mathrm{~mm}$ using a UV-visible detector. This particular wavelength was chosen by the absorption specters of the test and standard measures in a swept spectrophometer UV/Visible (Agilent, 8453) with good detection of height comparisons, separations and graphic peak resolutions. Efficient division of the components was achieved by shortening the division time through the use of a modified mixture of solvents: Solvent A, 2\% acetic acid in distilled water; and solvent B, acetonytril. The mixture of Solvent A and Solvent B was run through a linear gradient until it reached a $100 \%$ Solvent A in a time lapse of $10 \mathrm{~min}$, followed by $15 \mathrm{~min}$ of an isocratic run with Solvent B. Between every test injection, the column was rebalanced for a minimum of 10 minutes to eliminate the residual effects of the mixture caused by acetic acid (Skoog and Leary, 2001). Calibration curves were made for the following standards: gallic acid (Sigma Aldrich), catechin (Sigma Aldrich), rutin (Sigma Aldrich), morin (Fluka Analytical) and kaempferol (Sigma Aldrich). To validate the method, standardized and experimental tests were performed to determine the precision, selectivity, limit of detection, limits of quantification and linearity.

\section{Functional properties}

To determine water retention capacity (WRC), one gram flour was weighed and dispersed in $30 \mathrm{~mL} 2.0 \% \mathrm{NaCl}$ solution. The $\mathrm{pH}$ was adjusted to 7.0. Then, the solution was stirred for $10 \mathrm{~min}$ and heated to $85{ }^{\circ} \mathrm{C}$ for $15 \mathrm{~min}$. The samples were allowed to cool and then centrifuged (Hettich, Micro 220R, Germany) at 5000 $\mathrm{rpm}$ at $25^{\circ} \mathrm{C}$ for $15 \mathrm{~min}$. The supernatant was removed, and the sample was weighed on an analytical balance (Adam, PW 124), (Delgado and Albarracín, 2012).

To determine the water absorption index (WAI) and water solubility index (WSI), $2.5 \mathrm{~g}$ flour was weighed in a beaker, after which $50 \mathrm{~mL}$ distilled water was added, and the solution was stirred. A $10 \mathrm{~g}$ aliquot of the suspension was taken and centrifuged (Hettich, Micro 220R, Germany) at $3000 \mathrm{rpm}$ for $15 \mathrm{~min}$. The supernatant was decanted, and the pellet was dried at $100{ }^{\circ} \mathrm{C}$ for $24 \mathrm{~h}$ and then weighed on an analytical balance (Adam, PW 124), (Smith et al., 1973).

To determine the emulsifying capacity (EC), $6.7 \mathrm{~g}$ flour was dispersed in $100 \mathrm{~mL} 2.0 \% \mathrm{NaCl}$ solution and mixed for $10 \mathrm{~min}$. The $\mathrm{pH}$ was adjusted to a range of 6.5-7.0. Corn oil was added (to which liposoluble dye was previously placed) with agitation at a rate of $1 \mathrm{~mL}$ oil per second (Delgado and Albarracín, 2012).

\section{Microbiological tests}

Total coliforms, aerobic bacteria and molds and yeasts were determined in the flour samples at the beginning and during the storage time in order to determine the safety of the flours according to the Official Mexican Norm.

\section{Statistical Analysis}

Two-way ANOVA $(\alpha=0.05)$ was carried out, wherein the treatments were the types of quinoa, the categorical variables were the months of storage, and the dependent variables were the results obtained for each of the analytical determinations. Means were compared by means of a Tukey test $(\alpha=0.05)$. 


\section{Results and Discussion}

Figure 1 shows the newly obtained quinoa flours from Mexico and Chile initially and after storage; as no apparent changes in the color and odor of the flours were observed, we conclude that the use of metalized packaging helped.

Table 1 shows the results obtained for the different analytical determinations on the first day and during storage. In the case of humidity, no significant differences were observed between the flours at different months, nor was $15 \%$ humidity exceeded for the flours; this humidity is lower than that established in the NOM. Delgado and Albarracín (2012) obtained quinoa flour with a higher percentage of moisture (11.74\%), which was adequate to propose using quinoa as a "rubbery" material in meat products, replacing wheat flour.

The fat percentage in the quinoa from Chile presented a value significantly higher than the quinoa from Mexico (Table 1). The fat content depends on the genetic material, the state of maturity, soil fertility and climatic factors (Fuentes, 2008).

According to the data reported by Romo et al. (2006), the percentage of fiber (4.51\%) was similar to that obtained in this research for the Chilean flour (4.08\%), which was significantly higher than that obtained herein for the Mexican flour (Table 1). The importance of fiber content in foods is that it facilitates digestive transit, producing a feeling of fullness in addition to regulating cholesterol

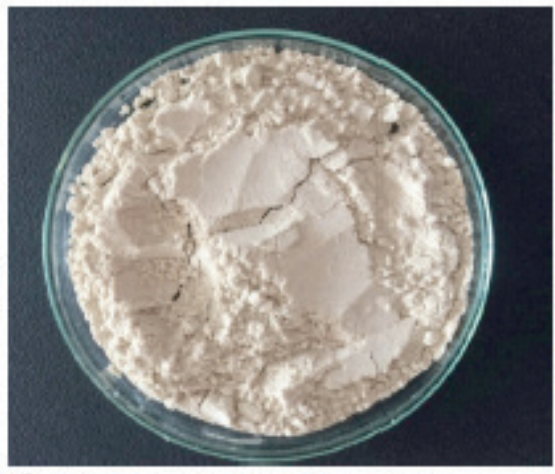

A

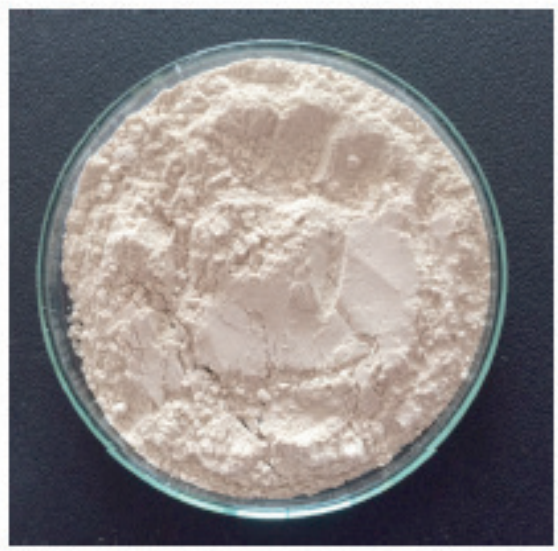

C

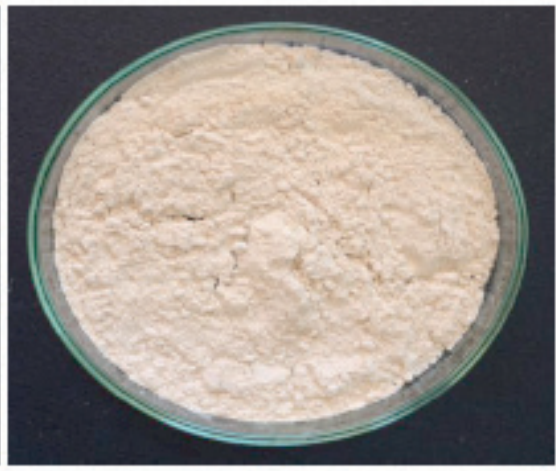

B

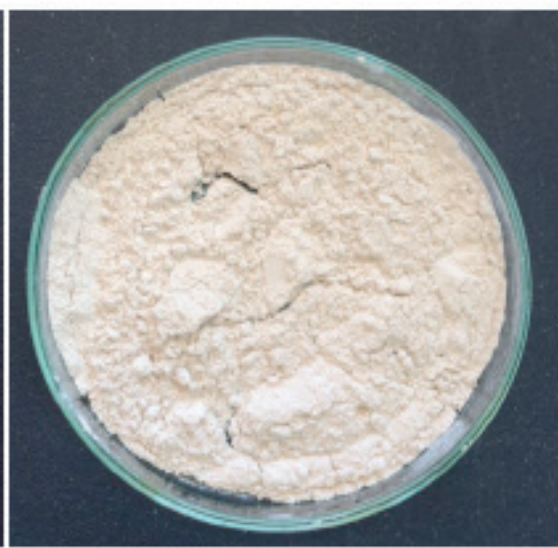

D

Figure 1. Chilean quinoa flour on the first day (A) and the sixth month (B); quinoa flour from Mexico on the first day (C) and the sixth month (D). 
Table 1. Initial and final values of the different analyses made to quinoa flours.

\begin{tabular}{|c|c|c|c|c|c|c|c|c|}
\hline Month & Country & $\begin{array}{c}\text { Humidity } \\
\%\end{array}$ & $\begin{array}{c}\text { Raw fat } \\
\%\end{array}$ & $\begin{array}{c}\text { Ashes } \\
\%\end{array}$ & $\begin{array}{c}\text { Proteins } \\
\%\end{array}$ & $\begin{array}{c}\text { Raw fiber } \\
\%\end{array}$ & $\begin{array}{l}\text { Carbohy } \\
\text { drates } \%\end{array}$ & $\begin{array}{c}\text { Reducing } \\
\text { sugar }\end{array}$ \\
\hline 0 & $\begin{array}{l}\text { Chile } \\
\text { México }\end{array}$ & $\begin{array}{l}9.5 \pm 0.54^{\mathrm{a}} \\
8.4 \pm 0.34^{\mathrm{b}}\end{array}$ & $\begin{array}{l}10.9 \pm 0.91^{\mathrm{a}} \\
7.64 \pm 0.63^{\mathrm{b}}\end{array}$ & $\begin{array}{l}3.54 \pm 0.21^{\mathrm{a}} \\
3.17 \pm 0.14^{\mathrm{a}}\end{array}$ & $\begin{array}{c}10.7 \pm 0.91^{\mathrm{a}} \\
8.4 \pm 0.69^{\mathrm{b}}\end{array}$ & $\begin{array}{l}4.08 \pm 0.25^{\mathrm{a}} \\
2.78 \pm 0.16^{\mathrm{b}}\end{array}$ & $\begin{array}{l}46.67 \pm 14.2^{\mathrm{a}} \\
59.78 \pm 26.3^{\mathrm{b}}\end{array}$ & $\begin{array}{l}7.3 \pm 0.15^{\mathrm{a}} \\
5.8 \pm 0.42^{\mathrm{a}}\end{array}$ \\
\hline 1 & $\begin{array}{l}\text { Chile } \\
\text { México }\end{array}$ & $\begin{array}{l}9.4 \pm 0.42^{\mathrm{a}} \\
8.5 \pm 0.22^{\mathrm{b}}\end{array}$ & $\begin{array}{l}10.8 \pm 0.57^{\mathrm{a}} \\
7.55 \pm 0.49^{\mathrm{b}}\end{array}$ & $\begin{array}{l}3.33 \pm 0.19^{\mathrm{a}} \\
3.24 \pm 0.20^{\mathrm{a}}\end{array}$ & $\begin{array}{c}10.6 \pm 0.75^{\mathrm{a}} \\
7.9 \pm 0.57^{\mathrm{b}}\end{array}$ & $\begin{array}{l}3.97 \pm 0.32^{\mathrm{a}} \\
2.65 \pm 0.21^{\mathrm{b}}\end{array}$ & $\begin{array}{l}45.16 \pm 12.2^{\mathrm{a}} \\
58.17 \pm 16.3^{\mathrm{b}}\end{array}$ & $\begin{array}{l}7.0 \pm 0.31^{\mathrm{a}} \\
5.7 \pm 0.29^{\mathrm{a}}\end{array}$ \\
\hline 2 & $\begin{array}{l}\text { Chile } \\
\text { México }\end{array}$ & $\begin{array}{l}9.4 \pm 0.39^{\mathrm{a}} \\
8.5 \pm 0.41^{\mathrm{b}}\end{array}$ & $\begin{array}{l}10.5 \pm 0.73^{\mathrm{a}} \\
7.33 \pm 0.63^{\mathrm{b}}\end{array}$ & $\begin{array}{l}3.29 \pm 0.30^{\mathrm{a}} \\
3.19 \pm 0.31^{\mathrm{a}}\end{array}$ & $\begin{array}{c}10.4 \pm 0.66^{\mathrm{a}} \\
8.1 \pm 0.72^{\mathrm{b}}\end{array}$ & $\begin{array}{l}3.89 \pm 0.47^{\mathrm{a}} \\
2.71 \pm 0.29^{\mathrm{b}}\end{array}$ & $\begin{array}{l}46.17 \pm 10.1^{\mathrm{a}} \\
59.01 \pm 9.13^{\mathrm{b}}\end{array}$ & $\begin{array}{l}7.1 \pm 0.33^{a} \\
5.3 \pm 0.35^{\text {a }}\end{array}$ \\
\hline 3 & $\begin{array}{l}\text { Chile } \\
\text { México }\end{array}$ & $\begin{array}{l}9.6 \pm 0.29^{\mathrm{a}} \\
8.6 \pm 0.18^{\mathrm{b}}\end{array}$ & $\begin{array}{l}10.7 \pm 0.49^{\mathrm{a}} \\
7.41 \pm 0.32^{\mathrm{b}}\end{array}$ & $\begin{array}{l}3.40 \pm 0.27^{\mathrm{a}} \\
3.11 \pm 0.25^{\mathrm{a}}\end{array}$ & $\begin{array}{c}10.6 \pm 0.83^{\mathrm{a}} \\
8.7 \pm 0.49^{\mathrm{b}}\end{array}$ & $\begin{array}{l}3.93 \pm 0.34^{\mathrm{a}} \\
2.63 \pm 0.18^{\mathrm{b}}\end{array}$ & $\begin{array}{l}46.23 \pm 11.7^{\mathrm{a}} \\
58.08 \pm 9.43^{\mathrm{b}}\end{array}$ & $\begin{array}{l}7.1 \pm 0.52^{\mathrm{a}} \\
5.5 \pm 0.27^{\mathrm{a}}\end{array}$ \\
\hline 4 & $\begin{array}{l}\text { Chile } \\
\text { México }\end{array}$ & $\begin{array}{l}9.6 \pm 0.37^{\mathrm{a}} \\
8.6 \pm 0.32^{\mathrm{b}}\end{array}$ & $\begin{array}{c}11.33 \pm 0.68^{\mathrm{a}} \\
7.39 \pm 0.41^{\mathrm{b}}\end{array}$ & $\begin{array}{l}3.25 \pm 0.12^{\mathrm{a}} \\
3.22 \pm 0.19^{\mathrm{a}}\end{array}$ & $\begin{array}{c}10.5 \pm 0.61^{\mathrm{a}} \\
8.5 \pm 0.51^{\mathrm{b}}\end{array}$ & $\begin{array}{l}4.01 \pm 0.29^{\mathrm{a}} \\
2.51 \pm 0.43^{\mathrm{b}}\end{array}$ & $\begin{array}{l}45.93 \pm 10.2^{\mathrm{a}} \\
57.98 \pm 12.5^{\mathrm{b}}\end{array}$ & $\begin{array}{l}7.3 \pm 0.21^{\mathrm{a}} \\
5.6 \pm 0.25^{\mathrm{a}}\end{array}$ \\
\hline 5 & $\begin{array}{l}\text { Chile } \\
\text { México }\end{array}$ & $\begin{array}{l}9.7 \pm 0.24^{\mathrm{a}} \\
8.5 \pm 0.47^{\mathrm{b}}\end{array}$ & $\begin{array}{c}11.21 \pm 0.71^{\mathrm{a}} \\
7.52 \pm 0.61^{\mathrm{b}}\end{array}$ & $\begin{array}{l}3.51 \pm 0.34^{\mathrm{a}} \\
3.15 \pm 0.22^{\mathrm{a}}\end{array}$ & $\begin{array}{c}10.7 \pm 0.59^{\mathrm{a}} \\
7.4 \pm 0.47^{\mathrm{b}}\end{array}$ & $\begin{array}{l}3.77 \pm 0.51^{\mathrm{a}} \\
2.60 \pm 0.37^{\mathrm{b}}\end{array}$ & $\begin{array}{c}46.61 \pm 10.5^{\mathrm{a}} \\
58.58 \pm 8.9^{\mathrm{b}}\end{array}$ & $\begin{array}{l}7.0 \pm 0.41^{\mathrm{a}} \\
5.6 \pm 0.36^{\mathrm{a}}\end{array}$ \\
\hline 6 & $\begin{array}{l}\text { Chile } \\
\text { México }\end{array}$ & $\begin{array}{l}9.8 \pm 0.33^{\mathrm{a}} \\
8.7 \pm 0.51^{\mathrm{b}}\end{array}$ & $\begin{array}{c}11.17 \pm 0.52^{\mathrm{a}} \\
7.22 \pm 0.39^{\mathrm{b}}\end{array}$ & $\begin{array}{l}3.19 \pm 0.45^{\mathrm{a}} \\
3.09 \pm 0.34^{\mathrm{a}}\end{array}$ & $\begin{array}{c}10.6 \pm 0.88^{\mathrm{a}} \\
7.7 \pm 0.61^{\mathrm{b}}\end{array}$ & $\begin{array}{l}3.85 \pm 0.23^{\mathrm{a}} \\
2.61 \pm 0.25^{\mathrm{b}}\end{array}$ & $\begin{array}{c}45.96 \pm 8.9^{\mathrm{a}} \\
58.81 \pm 9.11^{\mathrm{b}}\end{array}$ & $\begin{array}{l}7.0 \pm 0.37^{\mathrm{a}} \\
5.5 \pm 0.28^{\mathrm{a}}\end{array}$ \\
\hline
\end{tabular}

${ }^{\dagger}$ The determinations were made in triplicate. The data represent the mean \pm standard deviation. ${ }^{\star}$ Different letters indicate significant differences between columns.

levels and stimulating the development of bacterial flora (FAO, 2013).

No significant differences were observed between the ash values of the quinoa flours (Table 1). The percentage of ash implies the presence of individual constituents: chlorides, phosphates, calcium and iron. The quantities of these minerals can be affected by the removal of the husk or cover of the quinoa grain, as was shown in the comparisons of several varieties reported by Padrón, et al. (2014), in which they determined that environmental and soil conditions, such as alkalinity and salinity, would affect the values.

Table 1 also shows the protein results obtained for quinoa flours; the values obtained were significantly higher for Chile than for Mexico. Between 16 and $20 \%$ of the weight of a quinoa seed is made up of proteins of high biological value, including all the essential amino acids, which are required to be ingested with food. The importance of quinoa proteins lies in their quality (FAO, 2011); these quinoa seed proteins can also be affected by their geographic location and existing genotypes (Fuentes and Paredes-Gonzalez, 2014). Additionally, in recent studies, it has been reported (Aguilera, 2009) that thermal treatments can affect quinoa protein content; however, in this work, even when the grains were subjected to a drying process, no significant decrease in their protein contents were observed. In addition, the quality of quinoa protein is considered one of the most complete among cereals (Rodríguez, 2015).

According to the data reported by Romo et al. (2006), the percentage of fiber that they obtained was $4.51 \%$, similar to that obtained in this project for quinoa from Chile (4.08\%), which was significantly higher than that of Mexico (Table 1). The importance of fiber content in food is that it facilitates digestive transit, produces a feeling of fullness, regulates cholesterol levels and stimulates the development of bacterial flora (FAO, 2011). In addition, the general percentage of fiber gives quinoa seeds better aptitude for obese or overweight individuals. Genetic differences, developmental defense mechanisms, environmental differences in soils, and the use of chemical fertilizers may be factors affecting quinoa fiber content (Miranda et al., 2012).

The percentages of carbohydrates obtained are shown in Table 1. Significant differences were observed in the contents; however, carbohydrates remain the major component of quinoa. Carbohydrates are one of the largest groups of organic compounds found in nature, and together with 
proteins they form the main components of living organisms. Carbohydrates are an abundant and economical source of energy for human beings, and also provide different physiological effects on health, such as: energy supply, satiety effects, gastric emptying, blood glucose control and insulin metabolism, protein glycosylation, and metabolism of cholesterol and triglycerides (Maradini, et al., 2015; Abugoch, 2009).

Reducing sugar values were low in both flours (Table 1), which is considered desirable for this type of product, as it makes digestion easier so that the food can be recommended having a low glycemic index, which is particularly important for diabetic people (Hernández, 2015).

The polyphenols present in the quinoa of Chile (Table 2) were significantly higher than those present in the flour from Mexico; this is considered positive for this type of product, since currently the presence of polyphenols is associated with antioxidant activity (Techeira et al., 2014), which gives added value. Phenolic compounds or polyphenols constitute a wide group of chemical substances, are considered secondary metabolites of plants, and have different chemical structures and activities. Many of the benefits of foods of vegetable origin are associated predominantly with antioxidant activity; their protective role in cardiovascular diseases and cancer as well as in aging processes are related to the presence and content of this group of compounds (Padron, et al., 2014).

The flavonoid content was significantly higher in Chilean than in Mexican flour (Table 2), especially for catechin and routine values; the values of gallic acid were similar to those reported for other varieties of quinoa. Many health benefits of flavonoids have recently been reported due to their antioxidant capacity provided by their chemical structure, and they can be used to treat diseases related to inflammatory processes and cardiovascular disorders. Additionally, their hepatoprotective activity has been documented, including antiallergic, anticarcinogenic, and antibacterial activities, among others (Repo-Carrasco and Encina, 2008).

In terms of water retention capacity (WRC), similar results were obtained for the two flours in this study (Table 3) and for Delgado and Albarracin in 2012 (5.05 $\pm 0.59 \%)$, who used

Table 2. Initial and final values of the polyphenols and flavonoids of quinoa flours.

\begin{tabular}{lccccccc}
\hline \multirow{2}{*}{ Month } & \multirow{2}{*}{ Country } & Polyphenols & Flavonoids & Galic acid & Catequine & Rutine & Kaempherol \\
\hline 0 & Chile & $319.1 \pm 17.7^{\mathrm{a}}$ & $70.1 \pm 2.24^{\mathrm{a}}$ & $61.3 \pm 0.21^{\mathrm{a}}$ & $128 \pm 21.4^{\mathrm{a}}$ & $281 \pm 50.1^{\mathrm{a}}$ & $49.5 \pm 5.3^{\mathrm{a}}$ \\
& México & $180.4 \pm 21.8^{\mathrm{b}}$ & $25.4 \pm 1.18^{\mathrm{b}}$ & $27.3 \pm 3.1^{\mathrm{b}}$ & $86 \pm 11.9^{\mathrm{b}}$ & $109 \pm 21.2^{\mathrm{b}}$ & $29.7 \pm 4.1^{\mathrm{b}}$ \\
1 & Chile & $326.4 \pm 20.3^{\mathrm{a}}$ & $72.5 \pm 2.03^{\mathrm{a}}$ & $60.1 \pm 4.9^{\mathrm{a}}$ & $121 \pm 35.2^{\mathrm{a}}$ & $247 \pm 69.2^{\mathrm{a}}$ & $52.3 \pm 6.9^{\mathrm{a}}$ \\
& México & $179.2 \pm 15.6^{\mathrm{b}}$ & $26.1 \pm 1.22^{\mathrm{b}}$ & $29.1 \pm 1.5^{\mathrm{b}}$ & $89 \pm 22.5^{\mathrm{b}}$ & $98 \pm 30.1^{\mathrm{b}}$ & $31.2 \pm 5.2^{\mathrm{b}}$ \\
2 & Chile & $330.7 \pm 19.5^{\mathrm{a}}$ & $71.9 \pm 1.98^{\mathrm{a}}$ & $65.1 \pm 2.2^{\mathrm{a}}$ & $130 \pm 29.7^{\mathrm{a}}$ & $219 \pm 45.7^{\mathrm{a}}$ & $55.6 \pm 7.6^{\mathrm{a}}$ \\
& México & $165.3 \pm 32.7^{\mathrm{b}}$ & $21.9 \pm 0.98^{\mathrm{b}}$ & $31.2 \pm 2.9^{\mathrm{b}}$ & $81 \pm 15.8^{\mathrm{b}}$ & $103 \pm 25.4^{\mathrm{b}}$ & $27.5 \pm 3.9^{\mathrm{b}}$ \\
& Chile & $311.9 \pm 30.4^{\mathrm{a}}$ & $74.3 \pm 1.15^{\mathrm{a}}$ & $64.9 \pm 3.1^{\mathrm{a}}$ & $131 \pm 25.2^{\mathrm{a}}$ & $252 \pm 53.8^{\mathrm{a}}$ & $50.8 \pm 6.1^{\mathrm{a}}$ \\
& México & $169.7 \pm 29.1^{\mathrm{b}}$ & $23.51 \pm 1.1^{\mathrm{b}}$ & $27.3 \pm 4.5^{\mathrm{b}}$ & $90 \pm 17.2^{\mathrm{b}}$ & $112 \pm 32.6^{\mathrm{b}}$ & $30.4 \pm 4.9^{\mathrm{b}}$ \\
& Chile & $327.3 \pm 22.1^{\mathrm{a}}$ & $70.7 \pm 1.59^{\mathrm{a}}$ & $69.2 \pm 4.5^{\mathrm{a}}$ & $126 \pm 31.2^{\mathrm{a}}$ & $260 \pm 44.1^{\mathrm{a}}$ & $60.3 \pm 8.2^{\mathrm{a}}$ \\
& México & $171.5 \pm 24.8^{\mathrm{b}}$ & $24.2 \pm 1.09^{\mathrm{b}}$ & $24.9 \pm 7.8^{\mathrm{b}}$ & $84 \pm 17.3^{\mathrm{b}}$ & $119 \pm 21.7^{\mathrm{b}}$ & $33.1 \pm 3.3^{\mathrm{b}}$ \\
& Chile & $314.2 \pm 24.3^{\mathrm{a}}$ & $76.3 \pm 2.01^{\mathrm{a}}$ & $60.7 \pm 5.9^{\mathrm{a}}$ & $129 \pm 28.3^{\mathrm{a}}$ & $233 \pm 38.7^{\mathrm{a}}$ & $58.7 \pm 9.1^{\mathrm{a}}$ \\
& México & $177.9 \pm 30.1^{\mathrm{b}}$ & $29.1 \pm 1.31^{\mathrm{b}}$ & $30.8 \pm 3.2^{\mathrm{b}}$ & $85 \pm 12.4^{\mathrm{b}}$ & $107 \pm 29.2^{\mathrm{b}}$ & $29.8 \pm 5.1^{\mathrm{b}}$ \\
& Chile & $331.5 \pm 29.1^{\mathrm{a}}$ & $73.2 \pm 1.77^{\mathrm{a}}$ & $63.2 \pm 9.1^{\mathrm{a}}$ & $131 \pm 22.6^{\mathrm{a}}$ & $241 \pm 40.9^{\mathrm{a}}$ & $54.5 \pm 7.3^{\mathrm{a}}$ \\
& México & $174.3 \pm 28.1^{\mathrm{b}}$ & $27.1 \pm 1.03^{\mathrm{b}}$ & $33.1 \pm 5.9^{\mathrm{b}}$ & $89 \pm 39.5^{\mathrm{b}}$ & $99 \pm 18.5^{\mathrm{b}}$ & $30.7 \pm 4.6^{\mathrm{b}}$ \\
\hline
\end{tabular}

The determinations were made in triplicate. The data represent the mean \pm standard deviation. ${ }^{\ddagger}$ Different letters indicate significant differences between rows for time lapse $(\mathrm{P}<0.05)$. 
quinoa flour as a meat extender and proved that it could replace wheat flour. In the processes of mass formation, it is considered that the functional property of flours, related to water absorption capacity, tends to be one of the most important physicochemical properties of carbohydrates, since it is related to the degree of intermolecular association between starchy polymers. This feature contributes to the maintenance of moisture in some foods, as in the case of bakery and pastry products, as they can form a superficial layer that limits water loss (Aguilera, 2009).

Table 3 shows the average values of the water absorption index (WAI) and water solubility index (WSI); the results were similar for both types of flour and for that of Rodríguez et al. (2012), who used quinoa flour to make bread. Water solubility and water absorption are parameters show the magnitude of the interaction between the starch chains within amorphous and crystalline sections. The morphology, processing and composition of flours affect their functional properties, as do the contents of fats and proteins. In the present work, the highest fat and protein contents were found in the flour from Chile.

The emulsifying capacities obtained from the quinoa flours (Table 3) were lower than those presented by Delgado and Albarracin in 2012 (14.16\%) but higher than those reported for wheat flour $(7.46 \%)$. This capacity is a property sensitive to heat treatment, as has been observed in dehydrated legume flours (Aguilera, 2009).

Microbiological analyses of the quinoa flours were negative during the six months of storage, demonstrating that the packaging used was adequate to maintain safety control in the two types of flour, thus complying with the minimum established in the NOM.

\section{Conclusions}

The results of the analytical determinations of quinoa flours showed that the highest values

of fats, fibers and proteins as well as flavonoid and polyphenol contents were present in the Chilean flour. The most abundant compounds, catechins and rutin, did not show significant differences in values during the six months of storage. No growth of any type of microorganism was observed in the flours during storage. The results of the functional analyses were similar for both flours, so they represent an excellent option to partially or totally replace wheat; as an additional benefit, they do not contain gluten.

Table 3. Values obtained for the functional properties of quinoa flours during storage.

\begin{tabular}{|c|c|c|c|c|c|c|c|c|}
\hline Month & $\begin{array}{l}\text { WRC } \\
\text { Chile }\end{array}$ & $\begin{array}{l}\text { WRC } \\
\text { México }\end{array}$ & $\begin{array}{l}\text { WAI } \\
\text { Chile }\end{array}$ & $\begin{array}{l}\text { WAI } \\
\text { México }\end{array}$ & $\begin{array}{l}\text { WSI } \\
\text { Chile }\end{array}$ & $\begin{array}{l}\text { WSI } \\
\text { México }\end{array}$ & $\begin{array}{l}\text { EC } \\
\text { Chile }\end{array}$ & $\begin{array}{l}\text { EC } \\
\text { México }\end{array}$ \\
\hline & \multicolumn{8}{|c|}{$\%$} \\
\hline 0 & $5.55 \pm 0.44$ & $4.87 \pm 0.26$ & $2.34 \pm 0.08$ & $2.55 \pm 0.21$ & $7.39 \pm 0.17$ & $8.42 \pm 0.39$ & $10.1 \pm 0.2$ & $11.4 \pm 0.3$ \\
\hline 1 & $5.24 \pm 0.39$ & $4.65 \pm 0.31$ & $2.29 \pm 0.12$ & $2.49 \pm 0.19$ & $7.21 \pm 0.29$ & $8.55 \pm 0.41$ & $10.4 \pm 0.5$ & $11.1 \pm 0.2$ \\
\hline 2 & $5.31 \pm 0.22$ & $4.79 \pm 0.38$ & $2.18 \pm 0.17$ & $2.51 \pm 0.11$ & $7.33 \pm 0.21$ & $8.51 \pm 0.33$ & $10.3 \pm 0.3$ & $10.9 \pm 0.5$ \\
\hline 3 & $5.40 \pm 0.35$ & $4.66 \pm 0.34$ & $2.21 \pm 0.33$ & $2.41 \pm 0.15$ & $7.29 \pm 0.37$ & $8.42 \pm 0.55$ & $10.1 \pm 0.4$ & $11.2 \pm 0.3$ \\
\hline 4 & $5.64 \pm 0.28$ & $4.55 \pm 0.41$ & $2.11 \pm 0.40$ & $2.55 \pm 0.21$ & $7.31 \pm 0.25$ & $8.44 \pm 0.43$ & $9.9 \pm 0.6$ & $11.0 \pm 0.6$ \\
\hline 5 & $5.71 \pm 0.61$ & $4.39 \pm 0.27$ & $2.24 \pm 0.22$ & $2.37 \pm 0.19$ & $7.12 \pm 0.41$ & $8.31 \pm 0.56$ & $10.2 \pm 0.1$ & $11.3 \pm 0.4$ \\
\hline 6 & $5.80 \pm 0.33$ & $4.67 \pm 0.41$ & $2.33 \pm 0.31$ & $2.41 \pm 0.25$ & $7.27 \pm 0.36$ & $8.27 \pm 0.31$ & $10.1 \pm 0.4$ & $10.9 \pm 0.5$ \\
\hline
\end{tabular}

The determinations were made in triplicate. The data represent the mean \pm standard deviation. Different letters indicate significant differences between rows for time lapse $(\mathrm{P}<0.05)$. WRC water retention capacity, WAI water absorption index, WSI water solubility index, EC Emulsifying capacity. 


\section{Resumen}

A. Vázquez-Luna, F. Fuentes, E. Rivadeneyra, C. Hernández, y R. Díaz-Sobac. 2019. Contenido nutricional y propiedades funcionales de la harina de quinoa de Chile y México. Cien. Inv. Agr. 46(2): 144-153. El conocimiento relacionado con el mejoramiento genético de la quinoa ha aumentado en los últimos años, demostrando un avance efectivo en la obtención de características morfológicas destinadas a lograr la uniformidad en la cantidad y calidad de la producción obtenida en el campo. Para esta investigación, se obtuvo y caracterizó la harina de quinua cosechada en México y Chile, esta última mejorada geneticamente. A continuación, se realizó la determinación de humedad, grasas, fibra, carbohidratos, acidez, cenizas, proteínas, polifenoles totales y flavonoides totales. También se evaluaron las propiedades funcionales y se realizó un recuento microbiológico. No se observaron diferencias en el olor y el color de las harinas, ni hubo un cambio en la humedad durante 6 meses de almacenamiento. Los porcentajes iniciales de acidez, grasas, proteínas y cenizas fueron mayores en la harina chilena $(2.25,10.99$, 10.69 y $3.54 \%$, respectivamente), mientras que la harina de México presentó 1.75, 7.64, 8.4 y $3.17 \%$, respectivamente. Con respecto a la fibra cruda y los carbohidratos, los resultados obtenidos fueron menores para la harina chilena $(2.78$ y $59.78 \%$, respectivamente), mientras que la harina mexicana mostró 4.08 y 66,67\%, respectivamente. El contenido de flavonoides y polifenoles en la harina chilena fue superior al de México. Los resultados obtenidos revelan que el contenido nutrimental de la harina de quinoa chilena fue mejor que el de México. El crecimiento de mohos y levaduras se observó en el sexto mes para la harina mexicana; sin embargo, los valores no excedieron los límites de la NOM (Norma Oficial Mexicana) 247.

Palabras clave: Contenido nutrimental, propiedades funcionales, quinoa.

\section{References}

Abugoch, L. 2009. Quinoa (Chenopodium quinoa Willd.): Composition, Chemistry, Nutrional, and Functional Properties. Carbohydrates. USA: Elservier Inc. Advances in Food and Nutrition Research 58:1-25.

Aguilera, Y. 2009. Harinas de leguminosas deshidratadas: Caracterización Nutricional y Valoración de sus Propiedades Tecno-Funcionales (Tesis Doctoral). Universidad Autónoma de Madrid. Facultad de Ciencias. Departamento de Química Agrícola.

AOAC. 1996. Official Method of Analysis of the Association of Official Analytical Chemists. AOAC International, Arlington.

Arroyave, L., and C. Esguerra. 2006. Utilizacion de la harina de quinoa (Chenopodium quinoa Willd) en el proceso de panificación (Tesis de Licenciatura). Universidad de la Calle. Facultad de ingeniería de alimentos. Bogotá.

Delgado, C.N., and H.W. Albarracin. 2012. Microestructura y propiedades funcionales de harinas de quinoa (Chenopodium quinoa W) y Chachafruto (Erythrina edulis) potenciales extensores cárnicos. Vitae 19(1):S430-S432.

FAO. 2011. La Quinoa: cultivo milenario para contribuir a la seguridad alimentaria mundial.

FAO/INFOODS. 2013. Food Composition Database for Biodiversity Version http:/www.fao.org/ infoods/infoods/tablesanddatabases/faoinfoods databases/en/

Fuentes, F. (2008). Mejoramiento Genetico de la Quinoa. Agricultura del Desierto. 4:71-89.

Fuentes, F., and X. Paredes-Gonzalez. 2014. Perspectivas Nutracéuticas de la Quinua: Propiedades Biológicas y aplicaciones funcionales. Capitulo 3.5. En: Bazile, D., Bertero, D., Nieto, C., "Estado del arte de la quinua en el mundo en 2013": FAO (Santiago de Chile) y CIRAD, (Montpellier, Francia). pp 341-351

Hernández, J.R. 2015. La quinua, una opción para la nutrición del paciente con diabetes mellitus. Quinoa, an option for feeding of the diabetes mellitus patient. Revista Cubana de Endocrinología 26(3):304-312. 
Maradini, A., M. Pirozi, J. Da Silva, H. Pinheiro-Santana, J. Paes, and J. Reis. 2015. Quinoa: Nutritional, Functional and Antinutritional Aspects. Critical reviews in food science and nutrition pp.1-51.

Miranda, M., A. Vega, E. Martínez, J. López, M. Rodríguez, K. Henriquez, and F. Fuentes. 2012. Genetic diversity and comparison of physicochemical and nutritional characteristics of six quinoa (Chenopodium quinoa wild) genotypes cultived in Chile. Ciencia e Tecnología de Alimentos. 32(4):1-9.

Nielsen, S.S. (Ed) 2003. Food Analysis Laboratory Manual; Kluwer Academic/ Plenum Publishers, New York.

NORMA Oficial Mexicana NOM-247-SSA1-2008, Productos y servicios. Cereales y sus productos. Cereales, harinas de cereales, sémolas o semolinas. Alimentos a base de: cereales, semillas comestibles, de harinas, sémolas o semolinas o sus mezclas. Productos de panificación. Disposiciones y especificaciones sanitarias y nutrimentales. Métodos de prueba.

Norma Oficial Mexicana NOM-092-SSA1-1994, Bienes y servicios. método para la cuenta de bacterias aerobias en placa. 1995. México.

Norma Oficial Mexicana NOM-111-SSA1-1994, Bienes y servicios. método para la cuenta de mohos y levaduras en alimentos. Diario Oficial de la Federación. 1994. México

Padrón P.C., R. González, and A. Hernández. 2014. Semillas de quinoa (Chenopodium quinoa Willdenow): composición química y procesamiento. Aspectos relacionados con otras áreas. Revisión. Revista Venezolana de Ciencia y Tecnología de Alimentos. 5(2):166-218.

Repo-Carrasco, R., and Z.C.R. Encina. 2008. Determinación de la capacidad antioxidante y compuestos fenólicos de cereales andinos: Quinoa (Chenopodium quinoa), Kañiwa (Chenopodium pallidicaule) y Kiwicha (Amaranthus cuadatus). Rev. Soc. Quim. Perú, 74(2):85-99.

Rodríguez, J. 2015. La quinua, una opción para la nutrición del paciente con diabetes mellitus. Revista Cubana de Endocrinología 26(3):304-312.
Rodríguez, E., A. Lascano, and G. Sandoval. 2012. Harina de quinoa y papa en panificación. Revista U.D.C.A Actualidad \& Divulgación Científica. 15(1):199-207.

Romo, S., A. Rosero, C. Forero, and E. Cerón. 2006. Potencial nutricional de harinas de quinua (Chenopodium quinoa $\mathrm{w}$ ) variedad piartal en los andes colombianos. Biotecnología en el sector Agropecuario y Agroindustrial, 4:113-125.

Smith, G.C., Z.L. Carpenter, K.F. Mattil , and C.M. Cater. 1973. Efficacy of Protein additives as emulsion stabilizers in Frankfurters. J Food Sci. 38:849-855.

Taylor, J., P. Belton, and G. Kwaku. 2014. Incresing the utilizacon of sorghum, millets and pseudocereals: developments in the science of their phenolic phytochemicals, bifotification and protein functionality. Journal of Cereal Science. 59(3):257-275.

Techeira, N., L. Sívoli, B. Perdomo, A. Ramírez, and F. Sosa. 2014. Caracterización físicoquímica, funcional y nutricional de harinas crudas obtenidas a partir de diferentes variedades de yuca (Manihot esculenta Crantz), batata (Ipomoea batatas Lam) y ñame (Dioscorea alata), cultivadas en Venezuela. Interciencia, Marzo-Marzo, 191-197.

Torres y Torres, N., and A.R. Tovar-Palacio. 2009. La historia del uso de la soya en México, su valor nutricional y su efecto en la salud. Salud Pública de México, 51(3):246-254.

Vázquez, A., B.M.L. Cruz, S.M. Santiago, and R. Díaz-Sobac. 2015. Development of a gluten-free bread and enriched with quinoa. In $5^{\circ}$ Congreso Internacional de Biología, Química y Agronomía. Editorial UAG, Guadalajara, Jalisco.

Vázquez-Luna, A., F. Rivera-Cabrera, L.F. PerezFlores, and R. Díaz-Sobac. 2011. Effect of Rootstock on Mango Fruit Susceptibility to Infestation by Anastrepha obliqua. A. J. Econ. Entomol. 104(6):1991-1998. 2011. DOI: dx.doi. org/10.1603/EC11223

Villanueva, R. (2014). El gluten del trigo y su rol en la industria de la panificación. Ingeniería Industrial, pp. 231-246. 